\title{
INVESTIGATION OF THE RELATIONSHIP BETWEEN SOIL ORGANIC MATTER AND MAGNESIUM CONTENT
}

\author{
Judit Petö ${ }^{1^{*}}$, Attila Hüvely ${ }^{1}$, Viktor József Vojnich ${ }^{1}$, Imre Cserni ${ }^{2}$ \\ ${ }^{1}$ Department of Agricultural Science, Faculty of Horticulture and Rural Development, John von Neumann \\ University, Kecskemét, Hungary \\ ${ }^{2}$ professor emeritus of the Faculty of Horticulture and Rural Development, John von Neumann University, \\ Kecskemét, Hungary \\ https://doi.org/10.47833/2020.1.AGR.013
}

\section{Keywords: \\ Organic matter \\ Magnesium content \\ Nutrient supply \\ Sandy soil \\ Soil analysis}

\section{Article history:}

Received 2 Nov 2019

Revised 28 Nov 2019

Accepted 5 Dec 2019

\begin{abstract}
In our present study we show the results of the analysis of a large number of soil samples, processed in our accredited laboratory. Some of the physical and chemical properties of the soil and the possible relationships among them were also followed. The average organic matter content was in the low range but showed a significant variance. The results of our present preliminary procession confirm that organic matter content can highly influence nutrient - and in this way - easily absorbable magnesium content of the soil. Soil samples derived mainly from the Southern part of the Great Plain. Our results, based on the analysis of thousands of soil samples, also suggest, that organic fertilization and / or recycling of the organic matter is extremely important in the sandy soils, typical in our area, as it can have very beneficial effect on the fertility and the nutrient content of the soils and thus on the development of the cultivated crops.
\end{abstract}

\section{Introduction}

The physical structure and chemical properties of the soil fundamentally determine the fertility of the soil, the development of the crop and, consequently, the efficiency of the farming activity. Many factors influence soil nutrient storage and supply capacity, but their assessment and recognition is not always obvious [5].

The organic matter content of soil significantly affects the fertility and nutrient supply of soil in general $[6,7]$. Magnesium is an essential element of plant growing via fundamental biochemical processes like photosynthesis, enzymatic catalysis and other cell functions [2, 3]. In a soil, deficient in magnesium, the yield decreases and the quality deteriorate [1, 4]. Mg deficiency is increasingly common in Hungary, especially on acidic loose soils of the country [6].

In the laboratory of the Faculty of Horticulture and Rural Development we carry out physical and chemical analysis of the soil samples continuously. In our study we were on following the average level, variation and correlation between the abovementioned parameters.

\section{Materials and methods}

In the present study, we processed soil samples received in 2016 by the Faculty's Accredited Soil and Plant Testing Laboratory. Soil samples were taken by registered soil protection experts associated with the laboratory and to a large extent by farmers. The number of samples processed

\footnotetext{
* Corresponding author. Tel.: +36 76517661

E-mail address: peto.judit@kvk.uni-neumann.hu
} 
was over 5000. Most of the soil samples derived from vineyards and orchards, in the southern part of Great Plain. The organic matter content - referring humus content - was determined photometrically after potassium dichromate / sulfuric acid digestion (Figure 1). Determination range was from 0.2 to $4.0 \mathrm{~m} / \mathrm{m} \%$. Nutrient contents were determined from soil extracts prepared according to standard $1 \mathrm{~mol} / \mathrm{dm}^{3} \mathrm{KCl}$ extraction method. Mg content was measured by standard ICP-OES spectrometry (Horiba Jobin Yvon, 5-200 mg/kg, Figure 2). Pearson's linear correlation analysis was performed to reveal the relationships between the examined parameters, and the significant relationships were determined at significance levels of $5 \%, 2 \%, 1 \%$ and $0.1 \%$.

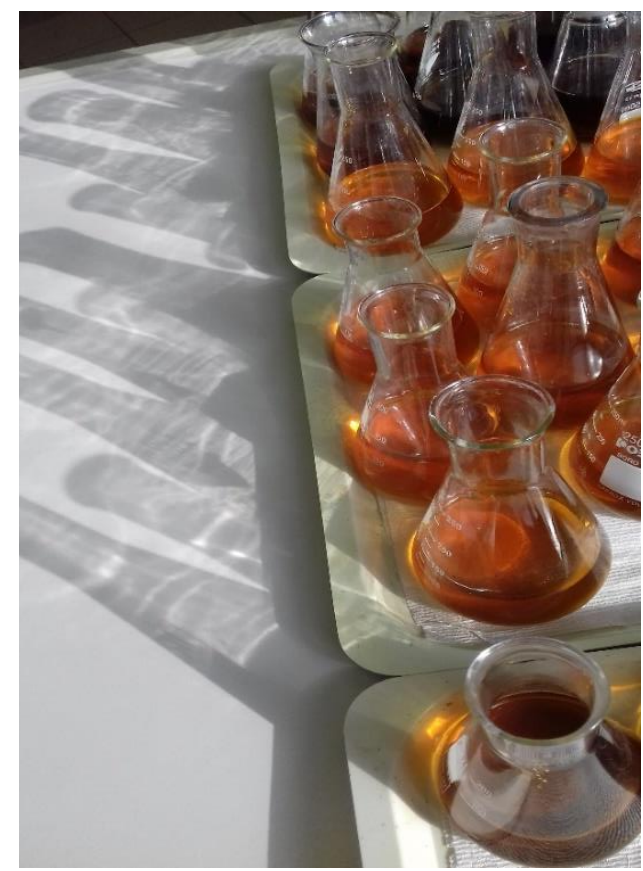

Figure 1. Prepared samples for organic matter content analysis

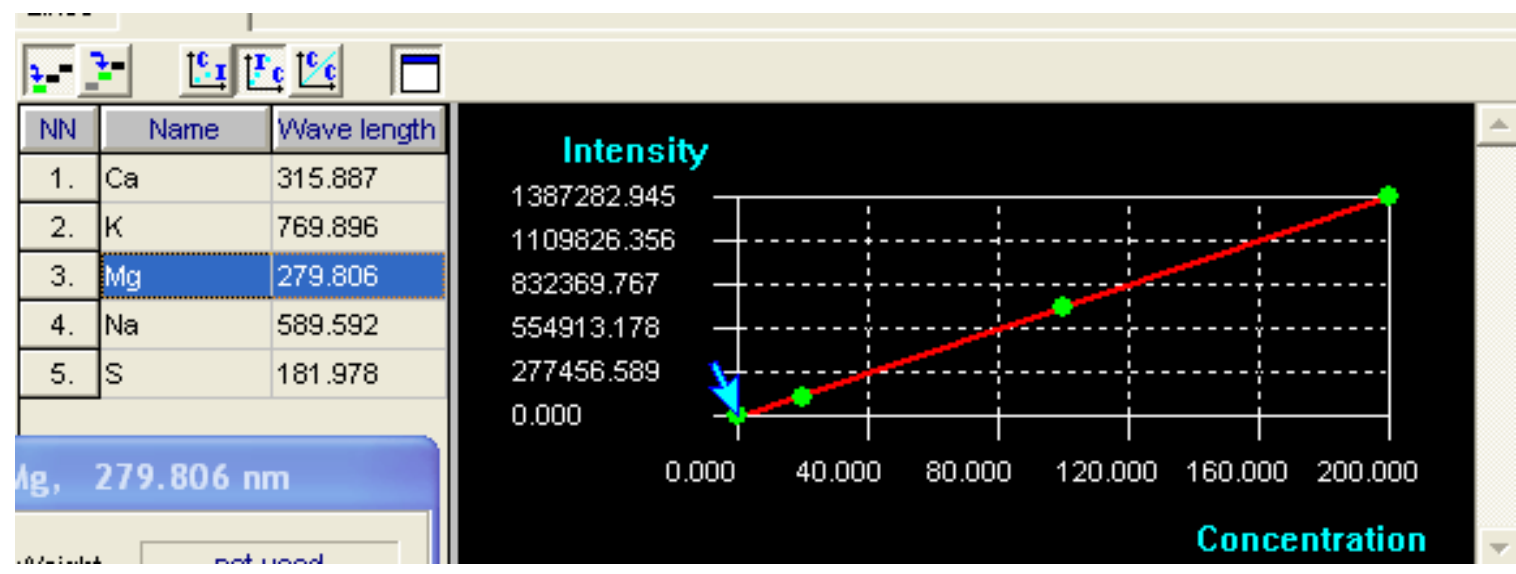

Figure 2. Magnesium calibration curve for ICP-OES measurement

\section{Results}

Most of the samples derived from the Southern Great Plain region of the country. Organic matter contents in the samples were generally low and showed significant variation (Table 1). Magnesium content was generally in the sufficiently high range, but also showed high extremities (Table 1). 
Table 1. Average concentration of organic matter and magnesium nutrient in the measured soil samples (2016)

\begin{tabular}{|l|c|c|}
\hline & $\begin{array}{c}\text { Organic matter } \\
\mathrm{m} / \mathrm{m} \%\end{array}$ & $\begin{array}{c}\text { Magnesium } \\
\mathrm{mg} / \mathrm{kg}\end{array}$ \\
\hline Average & 1.68 & 166 \\
\hline $\mathrm{SD}$ & 1.03 & 180 \\
\hline
\end{tabular}

The relationship between organic matter and magnesium content was evident, with a very strong positive correlation relationship $(r=0.6417, p<0.001)$.

\section{Discussion}

Magnesium exists in various form in mineral soils. From these, dissolved ionic form in the soil solution, and adsorbed ionic form on the colloid surfaces are available forms for plants. Strongly fixed compounds are not available for nutrient supply. The level of organic matter (humus) affects beneficially the availability of many of the essential nutrients as the physical conditions and biological activity of the soil improve in the presence of organic colloids [5]. Due to the proliferation of concentrated K-fertilizers Magnesium deficiency in soils is increasingly common in Hungary, especially in regions characterized with acidic loose texture [6].

It is necessary to apply regular addition of manures and magnesium fertilization on soils with poor magnesium supply and on Mg-demanding plants. Excessive potassium fertilizer use may lead to relative magnesium deficiency in many cases $[8,11]$.

Magnesium level in the soil showed high variation in our samples, and was in strong correlation with organic matter content. Average magnesium contents were in the moderate nutrient supply range. Soil samples derived mainly from vineyards, which are common in our region. Our former studies showed that magnesium deficiency was not characteristic in grape leaf samples, derived from our region [9]. Our current data show, that sandy soils with low humus content, but with moderate calcium-carbonate content and slightly alkaline $\mathrm{pH}$, are not in great risk of lack of magnesium [10]. However, in our area, we had to estimate the consequence of potassium deficiency rather than lack of magnesium in calcareous sandy soils.

Further studies are needed to follow the level and correlation of other nutrients, and to make further grouping of samples regarding type, depth and crop as well.

Organic fertilization and manure use are highly recommended to improve soil structure and nutrient supply.

\section{Conclusion}

Our results, based on the analysis of thousands of soil samples, suggest, that organic fertilization and / or recycling of the organic matter is extremely important in the sandy soils. Average organic matter content was in the low range but showed a significant variance, reflecting the heterogeneity of the soil characteristics. Magnesium contents were in the moderate nutrient supply range, and strongly dependent on humus content $(p<0.001)$. Increase of organic matter is extremely important in sandy soils, as it is essential effect on fertility, nutrient content and thus on cultivated crop.

\section{Acknowledgment}

Authors wish to thank for the support of the research carried out in the framework of the EFOP3.6.2-16-2017-00012 „Developing a functional, healthy and safe food product chain model from field to table in a thematic research network". The project is funded by the Hungarian State and the 
European Union, co-financed by the European Social Fund, and is part of the Széchenyi 2020 program.

\section{References}

[1] Cakmak, I., Yazici, A. M. (2010) Magnesium: a forgotten element in crop production. Better Crops, 94(2): pp. 2325.

[2] Dorenstouter, H., Pieters, G., Findenegg, G. (1985) Distribution of magnesium between chlorophyll and other photosynthetic functions in magnesium-deficient "sun" and "shade" leaves of poplar. Journal of Plant Nutrition, 8(12) pp. 1088-1101.

[3] Gerendás, J. , Führs, H. ( 2013) The significance of magnesium for crop quality. In Plant Soil, 368, pp. 101-128.

[4] Gransee, A., Fuhrs, H. (2013) Magnesium mobility in soils as a challenge for soil and plant analysis, magnesium fertilization and root uptake under adverse growth conditions. Plant and Soil, 368: pp. 5-21.

[5] Johnston, A. E. (1986). Soil organic matter, effects on soils and crops. Soil use and management, 2(3), pp. 97105.

[6] Kádár, I. (2015): Összefüggések a talaj termékenysége és tápanyagellátottsága között. MTA Talajtani és Agrokémiai Kutatóintézet (MTA ATK TAKI), 389. p.

[7] Károly L., Király I. (2017): Növekedés serkentő anyagok vizsgálata intenzív meggy ültetvényben, Gradus 4(2). pp. 141-147.

[8] Krempa, P., ložek, O., Slamka, P., Varga, L. (2009) Effectiveness of N-P-K-Mg-S fertilizers on yield and quality of grace-vine in Tokaj viniculture region. Agrochemistry, 49, pp. 23-27.

[9] Pető . J., Hüvely, A., Cserni, I. (2014) Makro- és mikroelemek transzlokációja szőlőültetvényekben. Gradus 1(1), pp. 292-297.

[10] Pető . J., Hüvely, A., Vojnich, V. J., Cserni, I. (2019) A talaj felvehető tápelemeinek összefüggése a vízoldható sótartalommal. Gradus, 6(2), pp. 33-38.

[11] Zlámalová, T., Elbl, J., Baroň, M., Bělíková, H., Lampiřr, L., Hlušek, J., Lošák, T. (2015) Using foliar applications of magnesium and potassium to improve yields and some qualitative parameters of vine grapes (Vitis vinifera, L.). Plant, Soil and Environment, 61, pp. 451-457. 